\title{
PIKIRAN POSITIF ALA NABI AYYUB AS
}

\author{
Harmaini \\ Fakultas Psikologi \\ Universitas Islam Negeri Sultan Syarif Kasim Riau \\ harmaini@uin-suska.ac.id
}

\begin{abstract}
Abstrak
Nabi Ayyub AS adalah seorang yang kaya raya, memiliki istri yang banyak dan juga anak. kemudian nabi Ayyub jatuh miskin dan kemudian ditimpakan penderitaan berupa sakit yang parah dalam waktu yang sangat lama. Dalam kondisi menderita, nabi Ayyub mengalami tiga kondisi sekaligus yaitu kesakitan, kesedihan dan kesendirian. Tiga kondisi yang dialami nabi Ayyub tidak merubah karakter nabi Ayyub seorang hamba yang taat, pemurah, penyanyang dan ikhlas dalam beribadah. Inilah bentuk lain dari optimisme yang ditunjukkan oleh nabi Ayyub. Tujuan penulisan adalah ingin menjelaskan secara psikologis bentuk pikiran positif cara nabi Ayyub. Hasil kajian kritis menemukan bahwa pikiran positif ala nabi Ayyub adalah merubah prasangka buruk menjadi prasangka baik (su'uzan menjadi husnuzan), sabar dalam kesakitan, kesedihan, kesendirian, dan kebersyukuran
\end{abstract}

Keyword : pikiran positif, nabi Ayyub AS

\section{THE POSITIVE MIND OF THE PROPHET OF AYYUB AS}

\begin{abstract}
The US Ayyub was a wealthy man, had many wives and children. then the prophet Ayyub fell poor and then inflicted suffering and then seriously ill for a very long time. In a state of suffering, the prophet Ayyub corrected three conditions at once namely pain, sadness and solitude. The three conditions experienced by the prophet Ayyub did not change the character of the prophet Ayyub, an obedient, generous, merciful and sincere servant in worship. This is another form of optimism produced by the prophet Ayyub. Job Job The results of a critical study found positive thoughts of the prophet Ayyub is to change bad prejudice into good prejudice (su'uzan to husnuzan), patience in pain, sadness, solitude, and gratitude
\end{abstract}

Keywords: positive thoughts, the prophet Ayyub AS

\section{Pendahuluan}

Allah berfirman dalam al Qur'an surat at Taubah ayat 105 yang artinya "Dan katakanlah bekerjalah kamu, maka Allah akan melihat pekerjaanmu, begitu juga Rasul-Nya dan orang-orang mukmin, dan kamu akan dikembalikan kepada Allah. Yang Mengetahui yang ghaib dan yang nyata, lalu diberitakan-Nya kepada kamu apa yang telah kamu kerjakan.". Sayyid Quthb (dalam Gulen, Muhammad Fetullah, 2014), Islam adalah manhaj akidah sedang amal yang diperbuat menjadi bukti akidah. Amal shaleh akan membenarkan nuraninya selalu dan mendustai godaan muslihat yang dihasilkan dari perasaan dan nafsunya. Islam adalah manhaj kehidupan yang realistis, tak cukup sekedar perasaan atau dengan niat baik saja. Sejatinya, niat itu punya kedudukan penting dalam 
amalan. Tapi keyakinan itu membutuhkan perbuatan nyata berupa amal shaleh di lapangan (Hamka, 2007). Niat tanpa amal ibarat hanya mau berencana tapi tidak mau melakukan. Artinya umat Islam harus ada ikhtiar atau pembuktian. Keharusan adanya ikhtiar karena hidup adalah perjuangan dan disetiap perjuangan pasti diiringi dengan usaha dan doa.

Setiap manusia mempunyai keinginan, harapan atau cita cita untuk memperoleh sesuatu mencapai kesuksesan, tidak ada seorang pun yang berkeinginan kegagalan. Hal tersebut Allah SWT telah menganugerahkan kehendaknya pada manusia. Apabila kehendak itu dapat dikelolah secara baik, maka manusia akan menemukan sebuah kesuksannnya sendiri. Dalam al-quran Allah berfirman yang artinya "kamu beriman pada Allah dan rasulnya serta berjihad berada dijalan allah dengan jiwa dan hartamu. Maka itulah yang lebih baik untuknya, bila kamu mengetahuinya" (QS. Ash-shaff:11). Dalam mencapai sesuatu kesuksesan, seseorang perlu belajar dengan membaca dan memahami isi ayat al Qur'an. Dalam al Qur'an terdapat kisah-kisah sebagai bahan pelajaran. Sesungguhnya pada kisah-kisah mereka itu terdapat pengajaran bagi orang-orang yang mempunyai akal. Al Qur'an itu bukanlah cerita yang dibuatbuat, akan tetapi membenarkan (kitab-kitab (yang sebelumnya dan menjelaskan segala sesuatu, dan sebagai petunjuk dan rahmat bagi kaum yang beriman. (QS. Yusuf: 111). Dan semua kisah dari rasul-rasul Kami ceritakan kepadamu, ialah kisah-kisah yang dengannya Kami teguhkan hatimu; dan dalam surat ini 3 telah datang kepadamu kebenaran serta pengajaran dan peringatan bagi orang-orang yang beriman. (QS. Hud: 120).

Kisah nabi Ayyub, diceritakan dua kondisi yang berbeda, pertama nabi Ayyub sebagai orang yang kaya raya (Tafsir Al-Baghawi, 17: 176) dan kedua, nabi Ayyub dalam keadaan sakit yang parah dan dalam waktu yang sangat lama (Tafsir Al-Qur'an Al-'Azhim, 5: 349). Dalam dua keadaan tersebut dikisahkan nabi Ayyub tetap dalam keadaan iman dan taqwa kepada Allah. Dan dalam dua keadaan tersebut banyak godaan dari iblis baik terhadap dirinya, istrinya dan anaknya. Rayuan dan cobaan yang dihadapi nabi Ayyub tidak hanya pada waktu kaya raya, tapi juga waktu tidak punya harta bahkan waktu sedang sakit. Cobaan dan rayuan terhadap diri nabi Ayyub tidak hanya datang dari iblis, tapi juga dari istri, anak dan saudara (M. Quraish Shihab. 2000). Keadaan ini menggambarkan bahwa nabi Ayyub selalu berpikiran positif terhadap keadaan yang dihadapi. Pikiran positif datang dari kepercayaan, pikiran negatif datang dari keragu-raguan; rasa takut yang benar adalah rasa takut yang digabungkan dengan harapan, karena itu lahir dari kepercayaan, serta kita berharap pada Tuhan yang kita yakini; sementara rasa takut yang salah digabungkan dengan keputusasaan, karena kita takut pada Tuhan; beberapa orang takut kehilangan-Nya, sementara yang lain takut mencarinya. Nabi Ayyub memiliki kepercayaan dan keyakinan akan keagungan Allah.

Pikiran positif terus dipelihara oleh nabi Ayyub dalam keadaan apapun dengan cara menyingkirkan hal-hal negatif yang ada dalam diri Nabi Ayyub serta terus menjaga diri dan keluarga dari godaan iblis, dan pembicaraan manusia tentang dirinya. Nabi Ayyub nampaknya sadar betul bahwa pikiran tersebut merupakan sebuah kekuatan untuk tetap membawanya pada kedekatan dengan Allah. Elfiky (2015) menjelaskan bahwa berpikir positif merupakan sumber kekuatan dan sumber kebebasan. Dikatakan sumber kekuatan karena bisa membantu seseorang memikirkan solusi sampai mendapatkannya sehingga seseorang bertambah mahir, percaya dan kuat. Sumber kebebasan karena mampu membebaskan seseorang dari kungkungan pikiran negatif serta pengaruhnya pada fisik. Kekuatan dan kebebasan yang dimiliki seseorang adalah buah dari berpikir positif, dan individu yang berpikir positif dapat dilihat melalui caranya menjelaskan peristiwa yang terjadi maupun belum terjadi. Cara individu menjelaskan peritiwa dikenal sebagai explanatory style 
atau gaya penjelasan. Gaya penjelasan merupakan suatu cara yang dimiliki individu dan berupa kebiasaan dalam memandang suatu peristiwa dalam kehidupannya yang kemudian ditunjukkan dengan bagaimana individu menjelaskan peristiwa tersebut. Pada intinya, kebiasaan berpikir individu tercermin dari bagaimana ia menjelaskan segala yang terjadi pada hidupnya (Seligman, 2006). Nabi Ayyub dalam menjalani tiga kondisi hidupnya yaitu kaya raya, miskin dan berpenyakit namun tetap dalam keadaan yaitu menyakini dalam diri dan pikirannya, tidak lalai dalam beribadah kepada Allah dan selalu berdoa dengan penuh rasa syukur.

\section{Profil Nabi Ayyub}

Nabi Ayyub adalah putra Nabi Yusuf, cucu dari Nabi Ishaq bin Ibrahim as. ibunya adalah putri dari Nabi Luth as. bin Harun saudara laki-laki Nabi Ibrohim as. Nama lengkap nabi Ayyub adalah Ayyub bin Mush bin Razah bin Al-'Ish bin Ishaq bin Ibrahim Al-Khalil. Sebagaimana disebutkan oleh Ibnu Ishaq dalam kitab Tarik Ath-Thabari. Ada juga ulama yang menyebutkan bahwa nama beliau adalah Ayyub bin Mush bin Raghwil bin Al-'Ish bin Ishaq bin Ya'qub. Ibnu 'Asakir menyebutkan bahwa ibu dari Nabi Ayyub adalah puteri Nabi Luth 'alaihis salam. Istri beliau sendiri adalah Layaa binti Ya'qub. Sedangkan yang paling masyhur, nama istri beliau adalah Rahmah binti Afraim bin Yusuf bin Ya'qub. (Al-Bidayah wa An-Nihayah, 1: 506).

Nabi Ayyub diutus oleh Allah kepada kaumnya dan mereka adalah penduduk Hauran dan Tih. Beliau diperintahkan oleh Allah untuk menyampaikan beberapa syariat dan membangun masjid untuk kaumnya dan menyeru kaumnya untuk menyembah Allah Swt. Nabi Ayyub adalah seorang yang sangat dermawan yang diceritakan, bahwa dirumahnya ada beberapa meja makan yang disediakan untuk orang-orang fakir-miskin dan serta untuk menjamu para tamu. Beliau mempunyai ternak yang bermacam-macam, seperti sapi, kambing, kuda, keledai, untah dan lain sebagainya yang terletak di daerah yang bernama Tsaniyah, di Huran, yang terletak di negeri Syam. Beliau orang yang baik hati, suka mengeluarkan harta bendanya untuk membantu fakir miskin, yatim piatu, memuliakan tamu dan sebagainya (Amin bin Abdullah asy-Syaqawi, 2010).

Ibnu Syihab mengatakan bahwa Anas menyebutkan bahwa Nabi Ayyub mendapat musibah selama 18 tahun. Wahb mengatakan selama pas hitungan tiga tahun. Ka'ab mengatakan bahwa Ayyub mengalami musibah selama 7 tahun, 7 bulan, 7 hari. Al-Hasan Al-Bashri menyatakan pula selama 7 tahun dan beberapa bulan. (Lihat Tafsir Al-Baghawi, 17: 181, juga lihat riwayat-riwayat dalam Tafsir Al-Qur'an Al-'Azhim, 5: 351). Namun Syaikh Muhammad Al-Amin Asy-Syinqithi rahimahullah menyatakan bahwa penyebutan jenis penyakitnya secara spesifik dan lamanya beliau menderita sakit sebenarnya berasal dari berita israiliyyat. (Adhwa' Al-Bayan, 4: 852).

Sebelum nabi Ayyub sakit, beliau adalah seorang laki-laki yang gagah dan memiliki istri yang saleh dan keturunan yang baik. Allah ingin mengujinya, dan Allah apabila mencintai suatu kaum, maka Allah menguji kaum tersebut, barangsiapa yang ridha dengan ujian tersebut, maka dia mendapatkan keridhaan Allah dan barangsiapa yang marah terhadap ujian tersebut, maka seseorang atau suatu kaum akan mendapatkan kemurkaan Allah (sebagaimana dalam hadis yang diriwayatkan oleh Tirmidzi dan Ibnu Majah, dihasankan oleh Syaikh Al Albani dalam Shahihul Jami' no. 2110, https://kisahmuslim.com/2553-kisah-nabi-ayyub-alaihis-salam.html). Penyakit nabi Ayyub yang tidak ada obatnya. Bahkan lebih memprihatinkan, badan Nabi Ayub membusuk sehingga banyak belatung menempel di tubuhnya, tidak ada sejengkalpun dari bagian tubuhnya yang membusuk karena penyakit kecuali hati dan lisannya. Akibat dari penyakit tersebut seluruh temannya merasa jijik

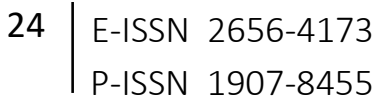


terhadapnya, sahabat karibnya menjadi tidak tenang dengannya, istri-istri nabi Ayyub, satu persatu meninggalkannya. Akhirnya dia diasingkan pada sebuah tempat pembuangan sampah di luar kota dis ebuah goa yang jauh dari tempat tinggalnya, dan tidak ada yang menemaninya kecuali seorang istrinya yang setia dan paling cantik di antara semua istri nabi Ayyub. Istri nabi Ayyub tersebut bekerja untuk mendapat upah dari orang lain, lalu dia membelikannya makanan, dibarengi dengan rasa sabar melepas semua harta dan anak, bersabar dengan penyakit suami setelah hidup dalam kenikmatan dan kehormatan yang pernah disandangnya. Derita nabi Ayyub tidak sampai disitu, karena masyarakat mengetahui bahwa wanita itu adalah istri Ayyub, orang-orang takut jika terkena dengan penyakit yang menimpa Ayyub atau tertular dengan penyakit melalui interaksi secara langsung dengan sang istri, akhirnya istri nabi Ayyub tidak menemukan seorangpun yang bisa memberinya pekerjaan yang mendatangkan upah. Lalu istri nabi Ayyub pergi menuju orang-orang yang kaya dan menggadaikan kepang rambutnya dengan makanan yang banyak lalu makanan itu dibawanya kepada Ayyub (Amin bin Abdullah asy-Syaqawi, 2010).

Setelah sekian lama menderita penyakit, Allah menyembuhkan penyakit nabi Ayyub, dan mengembaliikan harta kekayaan nabi Ayyub. Hal ini diterangkan dalam surat al Anbiyaa ayat 83 dan 84, artinya: "(Ya Tuhanku), Sesungguhnya aku telah ditimpa penyakit dan Engkau adalah Tuhan yang Maha Penyayang di antara semua Penyayang." (QS. al Anbiyaa': 83). Maka Allah mewahyukan kepada Ayyub agar menghentakkan kakinya ke tanah, lalu Ayyub melakukannya, tiba-tiba memancarlah air yang sejuk, kemudian ia mandi daripadanya, lalu Ayyub sembuh dengan izin Allah 'Azza wa Jalla. Tidak ada satu pun luka dan penyakit yang dirasakannya kecuali sembuh seluruhnya, ia juga meminum air itu, sehingga tidak ada satu penyakit yang ada dalam tubuhnya kecuali keluar dan dirinya kembali sehat seperti sebelumnya sebagai orang yang rupawan. Allah Subhanahu wa Ta'ala telah menghilangkan penyakit yang menimpa Ayyub dan jasadnya kembali sehat, Dia juga memberikan kekayaan lagi kepadanya, mengembalikan harta dan anaknya. Allah Subhanahu wa Ta'ala berfirman, artinya: "Dan Kami kembalikan keluarganya kepadanya, dan Kami lipatgandakan bilangan mereka, sebagai suatu rahmat dari sisi Kami dan untuk menjadi peringatan bagi semua yang menyembah Allah." (QS. al Anbiyaa': 84)

\section{Optimisme}

Scheier dan Carver (2002) mendefinisikan optimisme sebagai keyakinan individu secara umum akan hasil yang baik dari usahanya, yang kemudian mendorong individu tersebut untuk terus berusaha dalam mencapai tujuan, serta adanya keyakinan untuk selalu mendapatkan yang terbaik dalam hidupnya. Menurut Seligman (2014) optimisme adalah kebiasaan berpikir positif yang dilihat melalui gaya penjelasan individu terhadap peristiwa yang dialami atau yang belum dialami. Seligman membagi optimisme dalam tiga aspek yaitu:

1. Permanence. Permanence merupakan hal-hal yang berhubungan dengan waktu yaitu temporer atau permanen. Individu dalam menjelaskan penyebab suatu peristiwa (baik/ buruk) secara permanen atau temporer. Individu yang optimis jika menjelaskan penyebab peristiwa buruk bersifat temporer, sedangkan individu yang pesimis akan permanen. Pervasiveness yaitu menerangkan tentang pengaruh suatu peristiwa terhadap kehidupan seseorang artinya individu dalam menjelaskan penyebab suatu peristiwa secara spesifik atau global. Jika menghadapi peristiwa buruk individu yang optimis akan menjelaskan secara spesifik. Individu yang optimis 
menjelaskan peristiwa baik (good situation) pada diri mereka sendiri dengan penyebab yang bersifat permanen, sedangkan individu yang pesismis menganggap penyebab tersebut hanya bersifat sementara. Berbeda lagi dengan peristiwa yang buruk (bad situation) yang terjadi pada diri mereka. Individu yang optimis akan memandang peristiwa buruk sebagai sesuatu yang sementara dan kebetulan terjadi, sedangkan individu yang pesimis memandang bahwa peristiwa buruk bersifat permanen dan akan terus terjadi.

2. Pervasiveness. Pervasiveness adalah gaya penjelasan yang berkaitan dengan ruang lingkup peristiwa yang terjadi pada diri individu. Dimensi ini dibedakan menjadi menyeluruh atau khusus. Orang yang pesimis cenderung memberikan penjelasan yang menggeneralisir (pervasive) atas peristiwa buruk yang ada di sekelilingnya (misal: semua orang dalam berbisnis pasti bermain curang, atau semua peraturan memberatkan hidup, semua berita tentang pemerintah tidak ada yang benar dan beragam kalimat sejenisnya). Pervasive artinya kita menggeneralisasi akan sesuatu peristiwa atau kejadian. Dalam perisiwa yang baik (good situation), orang optimis akan menjelaskan bahwa hal tersebut disebabkan oleh faktor yang bersifat universal atau menyeluruh. Sedangkan orang yang pesimis, peristiwa yang baik akan menjelaskan bahwa hal tersebut terjadi untuk hal-hal tertentu saja (khusus). aspek pervasiveness menentukan apakah ketidak berdayaan akan melebar ke banyak situasi dan terbatas pada wilayah awalnya

3. Personalization. Dimensi ini merupakan gaya penjelasan yang berkaitan dengan sumber penyebab peristiwa dan dibedakan menjadi internal dan eksternal. Individu yang optimis akan menjelaskan peristiwa baik (good situation) seperti keberhasilan dikarenakan diri mereka sendiri. Individu yang optimis akan meyakini bahwa keberhasilan yang dicapai dikarenakan diri mereka sendiri yang berusaha keras. Hal ini menunjukan perhargaan terhadap diri sendiri dan tidak menganggap bahwa mereka sangat bergantung kepada orang lain. sedangkan orang yang pesimis akan menganggap keberhasilan sebagai sesuatu yang berhubungan erat dengan orang lain. seseorang yang pesimis tidak dapat meninggalkan orang lain sebagai penyebab keberhasilannya.

Scheier dan Carver (2001), menyebutkan bahwa konsep optimisme berfokus pada ekspektasi individu terhadap masa depan. Konsep ini memiliki ikatan dengan teori psikologi mengenai motivasi, yang disebut dengan expectancy - value theories. Teori ini dibagi Scheier dan Carver menjadi dua yaitu:

1. Tujuan (goals). Tujuan adalah tindakan, kondisi akhir, atau nilai yang individu lihat sebagai sesuatu yang diinginkan atau tidak diinginkan. Individu akan mencoba menyesuaikan perilaku, menyesuaikan dirinya terhadap apa yang ingin dicapai, dan individu akan mencoba untuk menghindari apa yang tidak mereka inginkan.

2. Harapan (expectancies). Merupakan perasaan percaya diri atau ragu-ragu mengenai kemampuan meraih tujuan (goal). Dengan adanya kepercayaan diri yang cukup individu akan berusaha untuk mencapai tujuan yang diinginkan. Optimisme akan mengarahkan individu untuk selalu memiliki harapan yang positif dan memiliki hasil yang baik akan masa depannya.

\section{Metode Penulisan}

Tulisan ini berdaasarkan bacaan dari 3 sumber utama yang berhubungan dengan kisah nabi Ayyub AS yaitu Tafsir Al-Qur'an Al-'Azhim. Cetakan pertama, tahun $1431 \mathrm{H}$. Al-Hafizh Ibnu Katsir. 
Penerbit Dar Ibnul Jauzi, Al-Bidayah wa An-Nihayah. Cetakan tahun $1436 \mathrm{H}$. Al-Hafizh Ibnu Katsir. Penerbit Dar 'Alam Al-Kutub, M. Quraish Shihab. Tahun 2000 dalam Tafsir Al-Misbah, dan Tafsir AlBaghawi (Ma'alim At-Tanzil), cetakan kedua, tahun $1427 \mathrm{H}$. Al-Husain bin Mas'ud Al-Baghawi penerbit Dar Thiybah. Sumber- sumber tersebut diambil kisah yang berhubungan dengan tujuan kajian yaitu adalah bagaimana dapat menjelaskan secara psikologis apa yang dialami oleh nabi Ayyub?. Penjelasan yang dimaksud adalah, nabi Ayyub dalam menghadapi penyakitnya tidak merasakan suatu kegalauan atau suatu tekanan. Nabi Ayyub nampak begitu optimis dalam menghadapi penyakitnya.

\section{Hasil dan Pembahasan}

Pertanyaan yang ingin dijawab dalam kajian kritis secara teoritis ini adalah bagaimana dapat menjelaskan secara psikologis apa yang dialami oleh nabi Ayyub?. Penjelasan yang dimaksud adalah, nabi Ayyub dalam menghadapi penyakitnya tidak merasakan suatu kegalauan atau suatu depresi. Nabi Ayyub nampak begitu optimis dalam menghadapi penyakitnya. Secara umum, elemen optimis bisa dijelaskan dari cara nabi Ayyub menjelaskan kejadian yang dialaminya selama hidup yaitu pernah menjadi kaya raya (good situation) dan merasakan sakit yang sangat lama (bad situation). Optimisme ala nabi Ayyub AS, nampak pada tiga hal yaitu: merubah prasangka buruk (su'uzan menjadi husnuzan), Sabar dalam kesakitan, kesedihan dan kesendirian dan kebersyukuran.

\section{Merubah Prasangka Buruk}

Imam al-Hafidz Ibnu Katsir pernah menuliskan kisah yang dikutip oleh Nor Kandir (2016) tentang kunjungan saudara nabi Ayyub pada saat sakit. Secara lengkap dituliskan "Ayahku bercerita, Abu Salamah bercerita, Jarir bin Hazim bercerita, dari 'Abdullah bin 'Ubaid bin 'Umair, ia berkata: "Ayyub 'alaihissalam mempunyai dua orang saudara. Suatu hari keduanya mengunjunginya. Mereka tidak kuat berdekatan dengan Ayyub karena baunya. Keduanya berdiri dari kejauhan. Salah satu dari keduanya berkata: "Andai Allah mengetahui kebaikan Ayyub, ia tidak akan tertimpa musibah ini." Ayyub pun sedih karena ucapan dua saudaranya itu, dengan kesedihan yang tidak pernah dirasakan olehnya. Kemudian nabi Ayyub berdoa: "Ya Allah, kiranya Kau tahu bahwa aku tidak pernah tidur (dalam keadaan) kenyang, padahal aku tahu (bagaimana susahnya) keadaan orang kelaparan, maka benarkanlah aku." Allah membenarkannya dari langit, dan kedua saudaranya mendengarnya. Kemudian Ayyub berdoa (lagi): "Ya Allah, kiranya Kau tahu bahwa aku tidak memiliki pakaian, padahal aku tahu (bagaimana susahnya) keadaan orang telanjang, maka benarkanlah aku." Allah membenarkannya (lagi) dari langit, dan kedua saudaranya mendengarnya. "Ya Allah, dengan keagungan-Mu," lalu Ayyub bersujud dan melanjutkan doanya, "Ya Allah, dengan keagungan-Mu aku tidak akan mengangkat kepalaku selamanya hingga Kau hilangkan (musibah ini) dariku." Kemudian Ayyub tidak mengangkat kepalanya hingga Allah menghilangkan (musibah/penyakit) darinya.

Dalam kisah yang lain, Imam Ahmad bin Hanbal, al-Zuhd, 1992, yang dikutp oleh Huzaimah Tahido Yanggo (1997) menuliskan sebuah kisah tentang nabi Ayyub yang artinya: "Beberapa orang dari Bani Israel melintasi (rumah) Ayyub 'alaihissalam, mereka berkata: "Penyakit yang menimpanya tidak lain karena dosa besar yang dilakukannya." Ayyub 'alaihissalam mendengar perkataan itu dan berdoa (QS. Al-Anbiya': 83): “(Tuhanku) aku telah terkena penyakit, dan Kau adalah Tuhan yang Maha Pengasih di antara semua pengasih." Sebelumnya Ayyub tidak pernah berdoa. (Imam Ahmad bin Hanbal, al-Zuhd, 1992). doa Nabi Ayyub memohon kesembuhan kepada Allah tidak didasari 
karena kesusahan dan keputusasaannya menjalani hidup dalam keadaan sakit, tapi ketidakrelaannya orang-orang yang berprasangka buruk kepada Allah. Penyakit yang menimpa diri nabi Ayyub dianngapnya tapi karena Allah ingin menguji dirinya bukan karena Allah tidak suka atau marah kepada nabi Ayyub. Personalization yang dimiliki nabi Ayyub menegaskan bahwa apa yang dideritanya adalah bentuk ujian dari Allah SWT. Doa ini juga secara tidak langsung untuk saudara nabi Ayyub yang berprasangka buruk kepada Allah. Karena menyempitkan rahmat-Nya yang luas dan kasih sayang-Nya yang tak berhingga. Seakan-akan Tuhan itu mudah marah dan pendendam. Riwayat kisah nabi Ayyub dapat kita pisah menjadi dua hal yang berhubungan dengan prasangka, yaitu:

1. Nabi Ayyub mengganggap (berprasangka) penyakitnya bukan karena Allah tidak suka atau marah, tapi karena Allah ingin menguji dirinya

2. Menghilangkan prasangka buruk dilakukan oleh orang yang melintasi rumahnya. seperti yang ada pada riwaqyat kedua. Saudara Ayyub mengatakan, penyakit Ayyub karena dosa-dosanya. Perkataan semacam itu, bagi nabi Ayyub, tidak bisa diterima. Bukan karena menyakiti perasaaannya, tapi karena prasangka buruk mereka kepada Allah, sehingga nabi Ayyub tidak bisa mendiamkannya.

Dalam literatur bahasa arab prasangka disebut dengan istilah zan. Kata zan dan pecahannya terdapat dalam al Qur'an pada 85 tempat, dan dalam penafsiran ayat- ayat yang mempergunakan kata zan, dapat ditarik kesimpulan bahwa kata zan memiliki beberapa arti, diantaranya (Mubarak Bakri. tt):

1. Yakin dan tahu secara pasti, seperti QS al-Muthaffifin : 4

2. Syak (Ragu) seperti dalam QS al Ghafir : 37

3. Tahaquq (Pemastian), seperti dalam QS al Kahfi : 53

4. Husban (Perkiraan), seperti dalam QS Shad/38:24

Al-zan merupakan hasil dari proses persepsi. Seseorang menerima informasi mengenai objek lalu mempersepsikannya. Persepsi merupakan merupakan perangkat yang dapat digunakan oleh seluruh makhluk. Namun, Allah swt memberikan perangkat persepsi lain yang dapat membedakan manusia dengan makhluk lainnya, yaitu akal. Sebenarnya, zan seseorang secara tidak langsung ditujukan pada Allah swt. (Tuhan manusia itu sendiri). Namun, hal itu diarahkan pada orang lain atau kelompok lain. Maka dari itu, tidak ada seorangpun yang bisa merdeka dari prasangka buruk ini, kecuali orang yang arif tahu akan Allah, Asma' dan Sifat-Nya, serta keyakinan adanya hikmah (kebaikan dibalik ciptaan Allah swt). Ini sesuai hadist yang berbunyi: "Sesungguhnya Allah mengikuti persangkaan hamba-Nya'. Oleh karena itu zan dapat dihilangkan dengan cara husnuzan (baik sangka) dalam melakukan persepsi yang didasari oleh kekuatan iman dan paham akan hikmah yang Allah tetapkan. Nabi Ayyub AS melakukan husnuzan dengan cara membaca doa dengan keras-keras supaya didengar oleh saudaranya yang datang dan meminta Allah untuk membenarkannya.

Persepsi nabi Ayyub terhadap penyakitnya dan terhadap diluar dirinya (orang lain, iblis dan Allah) sungguh suatu suatu persangkaan atas dasar persepsi yang lurus dan benar. Firman Allah dalam surat Shad ayat 41 artinya "dan ingatlah akan hamba Kami Ayyub ketika ia menyeru Tuhannya: "Sesungguhnya aku diganggu syaitan dengan kepayahan dan siksaan". Ayat ini ditafsirkan oleh M. Quraish Shihab dalam Tafsir Al-Misbah (2000), Nabi Ayub As. dalam ucapannya di atas tidak menggerutu tidak juga menyatakan bahwa apa yag dideritanya bersumber dari Allah, tetapi dari setan. Demikian beliu tidak menisbatkan sesuatu yang buruk kepadaNya. Disamping itu, walaupun apa yang beliau derita itu cukup berat, sebagaimana diisyaratkan oleh bentuk nakirah/indefinite 
pada kata nuhb dan adzab, beliau melukiskannya sebagai massani/aku telah disentuh bukan telah ditimpa. Penggunaan kata setan oleh Nabi Ayub dalam ucapannya itu bukan kata iblis yang dari segi bahasa mengandung makna keputusasaan, memberi kesan bahwa beliau sama sekali tidak berputus asa atas rahmat Allah. Ibn 'Asyur (dalam Ratu Suntiah dan Ruslandi, 2018) mengemukakan bahwa yang dimaksud oleh ayat di atas adalah bahwa setan tidak menyentuhnya dengan godaan dan bisikan-bisikan negatif yang disebabkan oleh kepayahan dan siksa yang sedang dialaminya. Jadi, bukan setan yang mengakibatkan kepayahan dan siksaan itu, tetapi kepayahan dan siksaan itu dijadikan setan sebagai dalih untuk menanamkan bisikan negatif berupa prasangka buruk terhadap Allah SWT., bisa juga huruf ba pada kata binushbin dalam arti bersama yakni, yakni aku disentuh oleh bisikan negatif setan bersama dengan kepayahan dan siksaan.

Menurut Selingman (2008), agama yang teratur menimbulkan kepercayaan bahwa ada yang lebih baik dalam kehidupan dari pada apa yang terlihat, kegagalan individu disanggah dengan kepercayaan akan bagian dari sesuatu yang lebih besar. Keyakinan akan kesembuhan dari Tuhan dan dukungan do'a membuat seseorang memiliki keinginan untuk melawan penyakit. Optimisme yang dimiliki nabi Ayyub memiliki peranan yang penting dalam mengurangi atau merubah prasangka terhadap pernyakitnya yang pada akhirnya berdampak pada proses penyembuhan penyakitnya. Berubahnya su'uzan menjadi husnuzan membuat nabi Ayyub memiliki harapan dan keyakinan untuk sembuh. Husnuzan meningkatkan kesehatan secara fisik dan psikologis, menghilangkan depresi, dan membuat seseorang berusaha lebih keras untuk mencapai harapannya. Husnuzan menjadikan aspek penting yang ada pada optimisme. Seligman (2008) berpendapat bahwa orang yang optimis jika dihadapkan pada situasi buruk, mereka akan mempersepsikan sebagai tantangan sehingga dia akan berusaha lebih keras lagi.

\section{Sabar dalam kesakitan, kesedihan dan kesendirian}

Sebuah ungkapan menyebut, sabar itu ilmu tingkat tinggi, belajarnya setiap hari, latihannya setiap saat, ujiannya sering mendadak, sekolahnya seumur hidup. Dan nabi Ayyub adalah manusia yang telah mencapai tingkatan tertinggi dalam sabar. Nabi Ayyub AS berada dalam tiga kondisi penderitaan sekaligus yang tidak mengenakkan yaitu kesakitan, kesedihan dan kesendirian. Kondisi sakit yang lama dan parah yang sebelumnya nabi Ayyub dalam keadaan sehat dan gagah, kondisi kesedihaan ditandai dengan menderita karena istrinya berhasil digoda iblis, kesendirian dirasakan nabi Ayyub dirasakan pada saat istri, anak-anaknya semua pergi bahkan orang lain tidak satupun yang mau menghamipiri nabi Ayyub. Belajar dari kondisi nabi Ayyub, dan ungkapan, berarti sabar bukanlah pasrah tidak berbuat, tapi aktif terus menerus berbuat dalam kebaikan. Firman Allah dalam QS Al-Ahqoof ayat 35), artinya "Maka bersabarlah kamu seperti kesabaran para rasul ulul azmi Allah mensifati para rasul yang sabar tersebut dengan "Ulul 'azmi", 'Azm dalam bahasa Arab artinya tekad yang kuat. Karenanya jika dalam keadaan bersabar bukan berarti pasrah dengan kondisi tanpa usaha. Sabar buakan pasrah tidak berbuat apa-apa tatkala menghadapi persoalan. Yafie, (dalam Najamuddin, 2018) mengemukakan bahwa ajaran Islam menganjurkan berbuat sesuatu untuk kelangsungan kehidupannya, maka sabar bisa berarti tegar, berdiri kokoh, atau tidak berputus asa ketika menghadapi rintangan, dan tetap berusaha secara maksimal.

Kitab At-Ta'rifat karangan As-Syarif Ali Muhammad Al-Jurjani (dalam Sukino, 2018) disebutkan bahwa sabar adalah, sikap untuk tidak mengeluh karena sakit, baik karena Allah Swt. apalagi bukan karena Allah Swt. Itulah sebabnya Allah Swt. memberikan pujian atau semacam 
penghargaan terhadap kesabaran nabi Ayyub As. Para ahli tasawuf menyebutkan sabar adalah merupakan sikap berani dalam menghadapi kesulitan-kesulitan. Menurut al-Kharraz (dalam anNajjar, 2004) sabar adalah sebuah nama yang mengandung makna-makna lahir dan batin. Sifat dari sabar bisa fisik, bisa juga bersifat psikis. Sifat sabar tersebut bermakna bahwa sabar adalah kemampuan mengendalikan emosi, selanjutnya al Kharraz membagi nama sabar berbeda-beda tergantung obyeknya. diantaranya:

1. Ketabahan menghadapi musibah, disebut sabar, kebalikannya adalah gelisah (jaza') dan keluh kesah (hala').

2. Menghadapi godaan hidup nikmat disebut, mampu menahan diri (dlobith an nafs), kebalikannya adalah tidak tahanan (bathar).

3. Kesabaran dalam peperangan disebut pemberani, kebalikannya disebut pengecut

4. Kesabaran dalam menahan marah disebut santun (hilm), kebalikannya disebut pemarah (tazammur).

5. Kesabaran dalam menghadapi bencana yang mencekam disebut lapang dada, kebalikannya disebut sempit dadanya.

6. Kesabaran dalam mendengar gossip disebut mampu menyembunyikan rahasia (katum),

7. Kesabaran terhadap kemewahan disebut zuhud,kebalikannya disebut serakah, loba (al hirsh)

8. Kesabaran dalam menerima yang sedikit disebut kaya hati (qana'ah), kebalikannya disebut tamak, rakus (syarahun)

Kedelapan nama kesabaran tersebut dimiliki oleh nabi Ayyub. Nabi Ayyub tidak pernah mengeluh tentang sakitnya (jaza'), nabi Ayyub dalam keadaan kaya raya dan sakit tetap bersyukur dan beribadah kepada Allah (dlobith an nafs), nabi Ayyub tidak pernah minta tolong pada orang lain pada saat kesakitan. Pada saat istri nabi Ayyub meminta supaya berdoa kepada Allah disembuhkan penyakitnya dan sangkaan saudara nabi Ayyub bahwa penyakitnya karena dosa besar yang telah dilakukan, nabi Ayyub tetap sabar dengan berdoa (hilm). Dalam keadaan miskin dan sakit, nabi Ayyub tidak pernah mengeluh dan selalu berprasangka baik kepada Allah, kemudian nabi Ayyub selalu sabar dalam menghadapi pembicaraan dan sindirian baik dari manusia atau iblis (katum). Dalam keadaan kaya raya, dalam keadaan sakit dan kaya raya kembali kondisi keimanan dan ketaqwaan nabi Ayyub tetap sama (al hirsh). Terakhir nabi Ayyub tidak pernah protes tentang penyakitnya yang parah dan lama (syarahun),.

Meminjam istilah Selingman (2006) nabi Ayyub optimis dimanapun, kondisi apapun dan dengan siapapun yang dihadapi karena semua itu adalah kehendak Allah (Pervasiveness). Hal ini dapat dilihat pada QS. al Anbiya' ayat 82, yang artinya "(Ya Tuhanku), sesungguhnya aku telah ditimpa penyakit dan Engkau adalah Tuhan Yang Maha Penyayang di antara semua penyayang.". Perhatikan doa Ayyub yang sangat hati-hati dan khawatir kalau dalam doanya terkandung keluhan yang menunjukkan ketidaksabaran Kemudian dalam hadist dari Anas bin Malik bahwa Nabi Muhammad SAW bersabda yang cukup dipanjang diceritakan, yang artinya:

"Sesungguhnya Nabi Allah, Ayyub bertahan dengan penuh kesabaran menghadapi berbagai penyakit dalam waktu delapan belas tahun, dia ditolak oleh kerabat dekat dan jauh kecuali dua lelaki dari saudaranya, keduanya selalu datang kepadanya baik pada waktu pagi atau sore. Suatu hari, salah seorang dari mereka berkata kepada yang lain: Apakah engkau mengetahui bahwa Ayyub telah berbuat dosa dengan dosa yang tidak pernah dikerjakan oleh seorangpun di dunia ini?. Maka teman yang satu bertanya: Dosa apakah yang pernah dilakukan oleh Ayyub?. Sahabat 
itu berkata: Sejak delapan belas tahun dia tidak pernah dikasihsayangi oleh Allah sehingga Allah menyembuhkan penyakit yang dideritanya. Lalu pada saat mereka berdua pergi menemui Nabi Ayyub salah seorang shahabatnya tidak berasabar menahan dirinya dan akhirnya menceritakan apa yang pernah didengarnya. Maka Ayyub berkata: Aku tidak memahami apa yang kalian katakan, hanya saja Allah mengetahui bahwa aku pernah melewati dua orang lelaki yang sedang bertikai, lalu mereka berdua mengingatkan nama Allah, lalu akupun kembali kerumahku dan aku membantu keduanya untuk menghapuskan kesalahan mereka, karena aku tidak suk mereka menyebut nama Allah kecuali untuk suatu kebenaran...".

Firman Allah dan hadist menggambarkan begitu sangat luar biasa kesabaran nabi Ayyub dalam hidup. Kesabaran nabi Ayyub tidak hanya untuk menenangkan dirinya tapi juga untuk menyelamatakan orang lain. Dalam expectancy - value theories, tujuan dan harapan kesabaran nabi Ayyub jelas dalam menghadapi kehidupan yang akan datang. Maka sangat wajar Allah memuji nabi Ayyub, seperti firman Allah dalam QS Shaad ayat 44, artinya: Sesungguhnya Kami dapati dia (Ayyub) seorang yang sabar. Dialah sebaik-baik hamba. Sesungguhnya dia amat taat (kepada Tuhan-nya)." Nabi Ayyub teleh menunjukkan kesabaran yang didasari oleh keimanan seperti QS al-Baqarah ayat 177 "Dan orang-orang yang sabar dalam kesempitan, penderitaan dan dalam peperangan. Mereka itulah orang-orang yang benar (imannya); dan mereka itulah orang-orang yang bertakwa". dan sebagai penolong dalam menghadapi keadaan penderitaannya, seperti firman Allah dalam QS alBaqarah ayat: 153 "Hai orang-orang yang beriman, jadikanlah sabar dan shalat sebagai penolongmu, sesungguhnya Allah bersama orang-orang yang sabar".

\section{Kebersyukuran}

Kecenderungan manusia adalah kepada kebaikan dan Allah menyediakan alat dan saranasarana untuk hidup dan kehidupannya selama di dunia, yakni berupa kemauan fitrah dan daya fikir. Kedua sarana ini, manusia akan mampu mengenal Allah. Mengenai pengenalan terhadap Allah, seorang ilmuwan Fransisco Jose Moreno (1985) menyatakan berpendapat bahwa dalam kehidupan sehari-harinya manusia dihadapkan pada pertanyaan-pertanyaan rasional tetapi selalu menemukan jawaban yang tidak rasional, seperti: kenapa harus mati? Kenapa Ada sakit dan sehat, Apa makna dan tujuan hidup? Siapakah yang menciptakan alam? Dan lain sebagainya. Jawaban dari banyak pertanyaan akan menunjukkan kepada sesuatu yang tidak bisa dipikirkan,yang didalamnya memiliki dua prinsip, yakni prinsip nilai (value) dan kepercayaan (belief). Menerima ide tentang Allah sebagai yang maha kuasa atas segalanya adalah sebuah nilai, sedangkan mengembalikan kejadian-kejadian khusus seperti kematian, sehat dan sakit, penciptaan alam kepada tanggung jawab Allah adalah sebuah kepercayaan. Pengakuan (tauhid = kepercayaan) tentang adanya Allah merupakan proses kejiwaan atau pengalaman spiritual yang dialami setiap manusia. Maka, hubungan manusia dengan Allah merupakan masalah kesadaran. Kesadaran yang dimaksud adalah adanya

Kebersykuran yang terwujud pada nabi Ayyub tidak hanya dalam bentuk thankfulness dan appreciative, tapi juga berbentuk Gratefulness (McCullough, Emmons, \& Tsang, 2002). Gratefulness dianggap sebagai bentuk transpersonal gratitude karena tidak hanya menekankan pada bentuk ekspresi maupun ungkapan terimakasih yang terlihat, akan tetapi mengarahkan pada kondisi kesadaran dalam diri yang lebih mendalam terkait dengan pengalaman yang dialaminya. Dalam konteks gratefulness individu tidak harus dihadapkan dengan sosok atau objek yang jelas untuk memunculkan rasa terimakasih tersebut. Lebih jauh dijelaskan bahwa jika dikaitkan dalam konteks 
agama dan spiritual, keberadaan Tuhan, takdir maupun kekuatan-kekuatan alam menjadi sosok terpenting sebagai faktor munculnya pengalaman akan rasa syukur ini (McCraty \& Childre, 2004). Dalam sebuah Hadist yang artinya: Dari Abu Hurairah radhiyallahu 'anhu, ia berkata bahwa Nabi shallallahu 'alaihi wa sallam bersabda, "Allah Ta'ala berfirman: Aku sesuai persangkaan hambaKu. Aku bersamanya ketika ia mengingat-Ku. Jika ia mengingat-Ku saat bersendirian, Aku akan mengingatnya dalam diri-Ku. Jika ia mengingat-Ku di suatu kumpulan, Aku akan mengingatnya di kumpulan yang lebih baik daripada pada itu (kumpulan malaikat)." (Muttafaqun 'alaih) (HR. Bukhari, no. 6970 dan Muslim, no. 2675)

Orang yang didalam pikirannya dipenuhi oleh hal-hal negatif, akan selalu memandang khidupan dunia sebagai sarana menuju ke arah yang lebih baik dan fana (akhirat) dalam kesempuranaan hidup, memandang sakit adalah bagian dari kehidupan, memandang kemiskinan sebagai kekayaan, memandang kekurangan sebagai kelengkapan dan memandang kegagalan dijadikan sebagai peluang kesuksesan. Pandangan ini didasari bahwa semua yang ada dan terjadi adalah sesuatu yang harus dihadapi dan diselesaikan dengan tetap menyerahkan diri kepada Allah sebagai bentuk pengakuan bahwa hanya Allah tempat berlindung dan berserah diri.

Pada kisah nabi Ayyub, pada saat kaya raya, semua harta habis, istri semuanya pergi dan anak-anak pun pergi menjauh. Pada saat miskin dan iblis menggoda dengan berkata, "Ayyub, untuk apa kamu terus ibadah, padahal anak istrimu telah meninggalkanmu." Nabi Ayyub menjawab, "Semua disekelilingku adalah titipan, termasuk diriku sendiri adalah titipan. Jadi, aku ikhlas dengan semua ketentuan Allah SWT." Penderitaan nabi Ayyub terus bertambah, iblis yang semakin marah mendengar jawaban Nabi Ayyub lalu meniupkan angin panas ke tubuh Nabi Ayyub yang mengakibatkan beliau terkena penyakit kulit yang sangat parah, bernanah, keluar bau yang tidak sedap, sampai masyarakat meminta kepada satu istrinya yang masih setia untuk membawa pergi Nabi Ayyub ke tempat yang jauh dari masyarakat. Dengan kondisi yang semakin parah, istrinya memohon kepada Nabi Ayyub agar berdoa kepada Allah SWT supaya disembuhkan penyakitnya. Namun Nabi Ayyub menjawab dengan perkataan yang menggetarkan hati, "Istriku, berapa lama kita bahagia dan berapa lama aku sakit? Rasanya aku malu meminta kepada Allah untuk disembuhkan padahal kenikmatanku lebih banyak daripada sakitku. Jawaban nabi Ayyub merupakan wujud dari kualitas syukur yang sangat sempurna, yang membuat beliau tetap berada dalam stamina iman yang kokoh dan kuat. Kekokohan iman tersebut merupakan bentuk dari pikiran positif nabi Ayyub, bahwa semua yang terjadi atas dirinya adalah kehendak Allah dan menganggap bahwa semua disekelilingnya adalah titipan, termasuk dirinya sendiri adalah titipan. Kebersyukuran nabi Ayyub dibuktikan bahwa Nabi Ayyub AS tidak hanya menyembah Allah ketika sehat dan diberi kekayaan, walupun sakit Nabi Ayyub AS tetap tiada lalai untuk beribadah kepada Allah SWT, yaitu hati tiada sepi-sepinya dari bersyukur kepada Allah SWT dan lidahnya tiada henti-hentinya menyebut nama Allah SWT.

Kisah nabi Ayyub berdoa seperti yang terdapat dalam QS al-Anbiya ayat 83-84. dalam menggambarkan keadaan dirinya ketika berdoa tidak lebih dari "ya tuhanku" sesungguhnya aku telah di timpa penyakit". Kemudian nabi Ayyub tidak berdoa sama sekali untuk mengubah dirinya, sebagai bentuk atas ujian itu. Nabi Ayyub adalah seorang hamba yang bersyukur bahwa dia masih punya Allah yang pasti akan mengobatinya. Doa yang dipanjtkan nabi Ayyub, menyatukan hati dan pikirannya menyatu untuk selalu dekat dengan Allah. Orang yang mudah meringankan hatinya untuk selalu bersyukur, akan merasa sangat menyayangkan sekali ketika hanya bisa menilai orang dari 
sudut pandang kelemahan mereka saja. Karena kesyukuran itu bukan hanya diterapkan kepada jalan hidupnya, namun juga dalam ringannya penerimaan orang lain untuk masuk ke dalam hatinya. Penyerahan diri bentuk dari diri yang tidak merasa sempit dadanya karena menerima ujian, dan merasa bosan dari penyakit yang menimpanya. Nabi Ayyub merasa sangat malu untuk memohon kepada tuhannya agar di keluarkan dari ujian itu, karena nikmat yang diterima lebih besar dan keadaan itu nabi Ayyub menyerahkan segala urusan sepenuhnya kepada Allah swt yang merupakan sikap tenang Nabi Ayyub AS

\section{Kesimpulan}

Kisah Nabi Ayyub AS menceritkan aspek teknologi dalam pemikiran yang paling sehat dan berhasil. Pikiran positif Nabi Ayyub mengatakan bahwa lebih lebih baik fisik yang membusuk daripada jiwa hatinya secara psikologis selama usia semasa hidupnya yang membusuk. Hati dan jiwa yang tidak membusuk telah menjadikan nabi Ayyub seorang manusia yang selalu menjada diri dan pikirannya untuk selalu berpikiran psitif dalam bentuk merubah prasangka buruk, sabar dalam kesakitan, kesedihan dan kesendirian dan terakhir selalu bersyukur dalam segala situasi dan kondisi. Keadaan ini mengantarkan nabi Ayyub yang seorang nabi yang mendapat pujian dari Allah

\section{Daftar Pustaka}

Adhwa' Al-Bayan fii lidhah Al-Qur'an bi Al-Qur'an. 1433 H/2012 M, Cetakan ketiga, tahun 1433 H. Syaikh Muhammad Al-Amin bin Muhammad Al-Mukhtar Asy-Syinqithi. Penerbit Dar 'Alam AlFawaid

Al Qur;an Digital, https://tafsirweb.com/

Albery \& Messer. 2005. Comparative Optimism About Health and Nonhealth Events in 8- and 9Yeard-Old Children. Health Psychology. Volume 24/ No 3: Halaman 316 -320.

Al-Bidayah wa An-Nihayah. 1436 H/2015 M, Cetakan tahun. Al-Hafizh Ibnu Katsir. Penerbit Dar 'Alam Al-Kutub

Al-Bidayah wa An-Nihayah. Cetakan tahun 1436 H. Al-Hafizh Ibnu Katsir. Penerbit Dar 'Alam Al-Kutub Al-Jami' li Ahkam Al-Qur'an. 1428 H/2007 M. Cetakan pertama, Muhammad bin Ahmad Al-Anshari Al-Qurthubi. Penerbit Darul Fikr

Al-Minhaj Syarh Shahih Muslim. 1433 H/2012 M, Cetakan pertama, Yahya bin Syarf An-Nawawi. Penerbit Dar Ibnu Hazm

Al-Minhaj Syarh Shahih Muslim. Cetakan pertama, Tahun 1433 H. Yahya bin Syarf An-Nawawi. Penerbit Dar Ibnu Hazm. 17:3-4

Amin bin Abdullah asy-Syaqawi, https://d1.islamhouse.com/data/id/ih fatawa/single/id Kisah Nabi Ayyub as.pdf

An-Najjar, Amin, 2004, Ilmu Jiwa dalam Tasawuf, Studi Komparatif dengan Ilmu Jiwa Kontemporer. Jakarta: Pustaka Azam

Departemen Agama RI. Al-Qur'an dan Terjemahnya; 2007, al-Jumanatul 'Ali. Seuntai Mutiara Yang Maha Luhur. Jakarta: J-ART. 
Elfiky, Ibrahim. 2015. Terapi Berpikir Positif :biarkan mukjizat dalam diri anda melesat agar hidup lebih sukses dan lebih bahagia, Penerjemah: Khalifurrahman Fath \&M. Taufik Daman. Jakarta : Zaman

Fransisco Jose Moreno, 1985, Agama Dan Akal Fikiran, terjemahan Indonesia oleh M. Amin Abdullah, Rajawali, Jakarta, 1985

Gulen, Muhammad Fetullah, (2014), As"ilatu al-„Ashar al-Mu hayyirah, Islam Rahmatan Lil „Alamin:

Menjawab Pertanyaan dan Kebutuhan Manusia. (terjemahan), Disunting oleh Hilman Subagyo \& Muh. Iqbal Santosa. Cetakan Ketiga. Jakarta: Republika

Hamka, (2007), Falsafah Hidup, Jakarta: Pustaka Antara

Huzaimah Tahido Yanggo, 1997, Pengantar Perbandingan Mazhab, Jakarta: Logos Wacana IImu, cet. ke-1

M. Quraish Shihab. 2000. Tafsir Al-Misbah. Jakarta: Lentera Hati

McCraty, R., \& Childre, D. (2004). The gratefull heart: The psychophysiology of appreciation. In Emmons, R. A., \& McCullough, M. E. (Eds) The Psychology of Gratitude. New York: Oxford University Press

McCullouh, M. E. \& Tsang, J-A. (2004). Parents of the virtues? The prosocial contours of gratitude. In Emmons, R. A., \& McCullough, M. E. (Eds) The Psychology of Gratitude. New York: Oxford University Press.

Mubarak Bakri, tt, file:///C:/Users/Acer/Downloads/322-Article\%20Text-413-1-10-20180815.pdf

Najamuddin, 2018, Kesabaran Dan Kesehatan Mental Dalam Bimbingan Konseling Islam, Tasamuh: Jurnal Studi Islamvolume 10, Nomor 1, April 2018, Pp. 241-272

Nor Kandir, 2016, Al-Qur'an Sumber Segala Ilmu, Pustaka Syubab

Ratu Suntiah dan Ruslandi, 2018. Nilai-Nilai Pendidikan Dalam Kisah Nabi Ayub As., (Tafsir Q.S. Shad Ayat 41-44), Jurnal Perspektif Vol. 2 No. 1 Mei 2018 Page 53-71

Scheier, M. F. \& Carver, C. S, 2002. Optimism Handbook of positive Psychology. New York: Oxford University Press

Scheier, M. F. \& Carver, C. S. 2001, Optimism, Pesimism, And Self-Regulation: Implication for Theory, Research, and Practice. Journal of American Psychological Assosiation. 31 - 51.

Seligman, M. E., \& Csikszentmihalyi, M. (2014). Positive psychology: An introduction (pp. 279-298). Springer Netherlands

Seligman, Martin. 2008. Menginstal Optimisme (edisi terjemahan). Translated by Budhy Yogapranata. 2008. Bandung: PT Karya Kita

Sukino, 2018, Konsep Sabar Dalam Al-Quran Dan Kontekstualisasinya Dalam Tujuan Hidup Manusia Melalui Pendidikan, Jurnal Ruhama Volume 1 No.1, Mei 2018

Tafsir Al-Baghawi (Ma'alim At-Tanzil). Cetakan kedua, tahun $1427 \mathrm{H}$. Al-Husain bin Mas'ud AlBaghawi. Penerbit Dar Thiybah

Tafsir Al-Qur'an Al-'Azhim. Cetakan pertama, tahun 1431 H. Al-Hafizh Ibnu Katsir. Penerbit Dar Ibnul Jauzi 